\title{
SRC rock mass classification of tunnels under high tectonic stress excavated in weak rocks
}

\author{
L.I. González de Vallejo* \\ Departamento de Geodinámica, Facultad de Ciencias Geologicas, Universidad Complutense de Madrid, 28040 Madrid, Spain
}

\begin{abstract}
This paper describes the application of the SRC rockmass classification system to tunnels under high horizontal tectonic stress excavated in weak rocks. The analysis was performed on 25 tunnels in Spain and Italy, for which it was found that much heavier supports than those estimated by the RMR index were required. SRC and RMR indices and other relevant geomechanical data were obtained during the site investigation and construction stages. Data corresponding to in situ stress measurements, analysis of tectonic structures and instability problems arising during construction were used to asses the state of stress.

The relationship between tunnel section convergence and the SRC and RMR indices was also analysed. Support measurements based on SRC and RMR classification were compared with those actually used during construction. These analyses indicate that for most of the tunnels examined, supports estimated using the SRC were much closer to those actually installed than those predicted by the RMR index.

Based on the case histories presented, the factors mainly contributing to deformability and consequently to assessing support measurements were: high horizontal tectonic stress, low strength of rocks, overburden thickness and structural anisotropy related to tunnel axis orientation. According to these factors, the tunnels investigated were classified as three types. Tunnels classed as type I were those of low overburden thickness under high horizontal tectonic stress excavated in low strength rocks. The supports installed for these tunnels were much heavier than those predicted by the RMR index, being more in line with those indicated by the SRC index. The type II tunnels had thick overburdens and showed similar stress and strength conditions to the former. The supports installed were practically those foreseen by the SRC index, appreciably differing with respect to the RMR index. Finally, tunnels included in the type III class were those under low to moderate tectonics stress, irrespective of overburden thickness. These tunnels gave rise to RMR and SRC indices that provided acceptable results.
\end{abstract}

Keywords: Rockmass classification; Geomechanical classification; Tectonic stress; In situ stress; Tunnels; Weak rocks

\section{Introduction}

The use of rock mass classification systems over the past 25 years has provided a vast amount of data and

\footnotetext{
* Fax: +34-91-3503876.

E-mail address: vallejo@geo.ucm.es (L.I. González de Vallejo).
}

allowed the evaluation of tunnels of different section, dimensions, overburden thickness, etc., affected by very different geological conditions. These years have also been witness to deformational processes in tunnels, both in the short- and long-term, due to reduced rock strength and to the rheological behaviour of the rockmass. Tunnel construction technology has also 
Table 1

Geomechanics rockmass classification $\mathbf{S} \mathbf{R}^{\mathrm{a}}$

Rock quality indexes Range of values

(1) lntact rock strength

Point-load test (MPa)

Uniaxial

$>8$

$>250$

2

strength $(\mathrm{MPa})$

Rating

(2) Spacing

or RQ

Spacing (m)

RQ $(\%)$

Rating

(3) Conditions of discontinuities

Rating

(4) Groundwater lnflow per 10-m tunnel length ( $/ / \mathrm{min})$

General conditions

Rating

(5) State of stresses

Competence factor ${ }^{b}$

Rating

Tectonic structures

$>2$

100-90

25

Very rough

surfaces

Not continuos

joints

No separation

Hard joint wall

30

None

ry

15

\section{$>10$ \\ 10}

Zones near thrusts/faults of regional importance

Rating -5

Stress relief factor ${ }^{c}$

$>200$

Rating

Neotectonic activity

Rating

$$
1
$$

None or unknown$$
\text { ( }
$$

Rock quality

Rating

I

Very good

$100-81$
$8-4$

$250-100$

15

$2-6$

90-75

20

Slightly rough Slightly rough surfaces

surfaces

Not continuos joints Not continuos joints

Separation $>1 \mathrm{~mm}$

Hard joint wall

25

$<10$

Slightly moist

10

$10-5$

5

Compression

$-2$

200-80

$-5$

Low

$-5$

II

Good

$80-61$
$5-3$
-5

Tension

Separation $1 \mathrm{~mm}$

Soft or weathered joint walls

2

$10-25$

-ccasional seepage 7

$-3$

(ension
$80-10$

High

$-10$
2-1 Not applicable

$50-25 \quad 25-5 \quad 5-1<1$

4

21

$\begin{array}{ll}0.2-0.06 & <\bullet .06 \\ 50-25 & <25 \\ 8 & 5\end{array}$

Slickensided surfaces surfaces

Continuous joints Continuous joints

Joints open 1-5 $\mathrm{mm}$ Joints open $<5 \mathrm{~mm}$ Gouge materials Gouge materials millimeter thick

10

$25-125 \quad>125$

Frequent seepage Abundant seepage

4

$<3$

$-10$

$<10 \quad$ Slopes

$200-8079-10<10$

$-8-10$

$-10-13-15$

III IV V

Fair Poor Very Poor

$60-41 \leq 40-21 \leq 20$

${ }^{a}$ After González de Vallejo (1985).

${ }^{\mathrm{b}}$ Uniaxial intact rock strength/vertical stress.

${ }^{\mathrm{c}}$ Ratio between the age of the last main orogenic deformation affecting the rock mass (in years $\times 10^{-3}$ ) and maximum overburden thickmess (in meters). 
undergone appreciable change over this period, in that excavation and support systems have evelved towards integrative mechanisation capable of boring large sections. All these technoløgical developments have been based on a more complete understanding of factors conditioning the behaviour and stability of rock masses, among which the state of stress of the rock plays a key role.

The importance of in situ stress in the design of underground excavations has been discussed extensively by Hoek and Brown (1980), Herget (1988), Hudsøn and Harrisøn (1997), etc. In general, data on in situ stress determinations indicate maximum horizontal stress exceeds vertical stress in most cases at depths under $500 \mathrm{~m}$, while these tend to balance $\bullet$ ut beyond a depth of $1000 \mathrm{~m}$. These stresses are mainly due to tectonic and gravitational forces, tectonic stresses being of most significance in turmelling.

Based on data derived from applying SRC and RMR classification systems to 25 turmels, in which support measurements had been underestimated by the RMR index, these classification systems were evaluated in terms of their suitability for tunnels in weak røcks affected by high hørizøntal tectønic stress. This was undertaken by comparing supports estimate by SRC and RMR indices with those actually installed. The $\boldsymbol{Q}$ system was $\bullet$ ccasional applied and only partial results were obtained for this index. This analysis was then used to identify the key factors that need to be considered when assessing deformability and supports based on rock mass classification.

\section{SRC classification}

The surface rock classification (SRC) system (Gønzález de Vallejø, 1983, 1985) was develøped from the RMR index to take inte account in situ stress, data from outcrops and turmel construction conditions. The SRC index is calculated from the parameters shown in Table 1, to which the correction factors shown in Table 2 are applied. The scores -btained and the corresponding røck classes geømechanically classify the rock mass in conditions prior to excavation and represent the SRC basic. T• account for effects due to construction conditions, the correction factors shown in Table 3 are applied to give the
Table 2

Adjusment to ratings to account for surface data for the geomechanics rockmass classification $\mathrm{SRC}^{\mathrm{a}}$

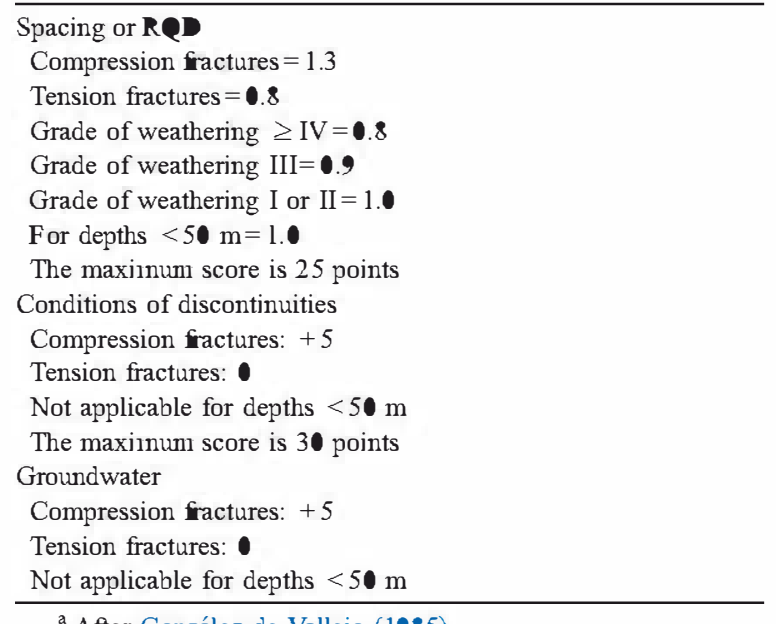

${ }^{a}$ After González de Vallejo (1985).

SRC-corrected. T• characterise the properties of the rock mass and estimate support measurements, the criteria use in RMR classification are directly applied to the value obtained for the SRC. Thus, the same RMR rockmass classes and their support measurements are used in SRC (Table 4).

\section{In situ stress in rock mass classification}

In general, the state of stress has hardly been considere in rock mass classification systems. The RMR calculation procedure (Bieniawski, 1973, 1979) does not account for the state of stress, although it is recommended that an adjustment factor of 0.6 for in situ stress be applied to the RMR value for mining applications (Bieniawski, 1989).

The 2 system (Barton et al., 1974; Barton and Grismtad, 1994) considers the state of stress in the stress reduction factor (SRF) which is determined from the four factors:

(a) presence $\bullet$ planes $\bullet$ weakness.

(b) $\sigma_{\mathrm{c}} / \sigma_{1}$ and $\sigma_{\theta} / \sigma_{\mathrm{c}}$ ratios in competent recks under stress.

(c) presence $\bullet$ squeezing rocks $\bullet$ plastic deformation under high pressure.

(d) presence of swelling rocks in the excavation. 
The total rating from Table 1 must be adjusted for the following factors:

Excavation methods

Tumneling boring machines, continuos miner, cutter machines, roadheaders, etc.

Con rolled blasting, presplitting, soft blasting, etc.

Poor-quality blasting ${ }^{\mathrm{b}}$

-

$-10$

\section{Supp $\bullet$ rt methods ${ }^{\mathrm{C}}$}

Class I

Class II

$<10 \mathrm{~d}$

$>10-<20 \mathrm{~d}$

$>20 \mathrm{~d}$

Class III

$<2$ d

$>2-<5 d$

$>5-<10 \mathrm{~d}$

$>10 \mathrm{~d}$

Classes IV and V

$<8 \mathrm{~h}$

$>8-<24 \mathrm{~h}$

$>24 \mathrm{~h}$

Distance to adjacent excavation

$\mathrm{AEF}<2.5$

Portals, accesses and areas with small overburden thickness ${ }^{\circ}$

$\mathrm{PF}<3$

Rock resistance to weathering ${ }^{\mathrm{f}}$

Rock of high durability (low clay content)

Rock of low durability (high clay content)

Rock of very low durability (very high clay content)

Discontinuity orientations ${ }^{*}$

Strike perpendicular to tunnel axis

Strike parallel to tunnel axis

Dip $-20^{\bullet}$ at any direction

Drive with dip

Dip 45-90*

Dip $2-45^{\circ}$

Drive against dip

(very favourable)

(favourable)

(fair)

$-5$
Dip $20-45^{\circ}$

(unfavourable)

$-10$ Dip $45-\mathbf{9 0}^{\circ}$
(very unfavourable)
-12
Dip $20-45^{\circ}$

(fair)

$-5$
Unfavourable

${ }^{a}$ After González de Vallejo (1985)

b Conventional blasting: 1

${ }^{\mathrm{C}}$ Based on Bieniawski's (1979) graphic represention of the stand-up time and the unsupported span, the ratings are applied in relation to the maximum stand-up time. d: days, h: hours.

AEF is the adjacent excavation factor, defined as the ratio between the distance to an adjacent excavation (in meters) from the excavation under design and the span of the adjacent excavation (in meters).

${ }^{\mathrm{e}} \mathrm{PF}$ is the portal factor, defined as the ratio between the thickess of overburden and the span of the excavation, both in meters.

${ }^{\mathrm{f}}$ Durability can be assessed by the slake durability test, or indirectly by the clay content.

* After Bieniawski (1979).

Factor (a) is an indicator of accumulated tectonic stresses, but these planes alsø •ccur in decompressed røck masses and in areas of tectonic extension, whose residual stresses have already been released and, thus, the influence of tectonic stress is uncertain. Factors (b) and (c) are relate to the lithostatic load and the 


\begin{tabular}{|c|c|c|c|c|}
\hline Rock mass class & Excavation & $\begin{array}{l}\text { Rock bolts } \\
\text { (20-mm diameter, fully grouted) }\end{array}$ & Shotcrete & Steel sets \\
\hline $\begin{array}{l}\text { (I) Very good rock, } \\
\text { RMR: } 81-100\end{array}$ & Full face, $3 \mathrm{~m}$ advance & $\begin{array}{l}\text { Generally no support } \\
\text { required except spot bolting. }\end{array}$ & & \\
\hline $\begin{array}{l}\text { (II) Good rock, } \\
\text { RMR: } 61-\mathbf{8 0}\end{array}$ & $\begin{array}{l}\text { Full face, } 1-1.5 \mathrm{~m} \text { advance; } \\
\text { complete support } 20 \mathrm{~m} \\
\text { from face }\end{array}$ & $\begin{array}{l}\text { Locally, bolts } 4 \mathrm{~m} \text { long, } \\
\text { spaced } 1.5-2 \mathrm{~m} \text { in crown }\end{array}$ & $\begin{array}{l}50 \mathrm{~mm} \text { in crown } \\
\text { where required }\end{array}$ & None \\
\hline $\begin{array}{l}\text { (IV) Poor rock, } \\
\text { RMR: } 21-4\end{array}$ & $\begin{array}{l}\text { Top heading and bench } \\
1.0-1.5 \mathrm{~m} \text { advance in } \\
\text { top heading; install } \\
\text { support concurrently with } \\
\text { excavation, } 10 \mathrm{~m} \text { from face }\end{array}$ & $\begin{array}{l}\text { Systematic bolts } 4-5 \mathrm{~m} \text { long, } \\
\text { spaced } 1-1.5 \mathrm{~m} \text { in crown } \\
\text { and wall with wire mesh }\end{array}$ & $\begin{array}{l}100-150 \mathrm{~mm} \text { in crown } \\
\text { and } 100 \mathrm{~mm} \text { in sides }\end{array}$ & $\begin{array}{l}\text { Light to medium } \\
\text { ribs spaced } 1.5 \mathrm{~m} \\
\text { where required }\end{array}$ \\
\hline $\begin{array}{l}\text { (V) Very poor rock, } \\
\text { RMR: }<2\end{array}$ & $\begin{array}{l}\text { Multiple drifts } 0.5-1.5 \mathrm{~m} \\
\text { advance in top heading; } \\
\text { install support concurrently } \\
\text { with excavation; shotcrete } \\
\text { as soon as possible after } \\
\text { blasting }\end{array}$ & $\begin{array}{l}\text { Systematic bolts } 5-6 \mathrm{~m} \text { long, } \\
\text { spaced } 1-1.5 \mathrm{~m} \text { in crown } \\
\text { and wall with wire mesh; } \\
\text { bolt invert }\end{array}$ & $\begin{array}{l}150-200 \mathrm{~mm} \text { in crown, } \\
150 \mathrm{~mm} \text { in sides and } \\
50 \mathrm{~mm} \text { on face }\end{array}$ & $\begin{array}{l}\text { Medium to heavy ribs } \\
\text { spaced } 0.75 \mathrm{~m} \text { with steel } \\
\text { lagging and forepoling } \\
\text { if required; close invert }\end{array}$ \\
\hline
\end{tabular}

${ }^{a}$ After Bieniawski (1989).

strength $\bullet$ the rocks, whereas factor (d) depends on the chemical composition of the rocks and the presence of water.

In SRC classification, the following parameters are used to asses the state of stress:

(a) competence factor: $\sigma_{\mathrm{c}} / \sigma_{1}$.

(b) tectonic accidents of regiønal magnitude present $\bullet$ near the site and their tectonic regime.

(c) stress relief factor, expressed as the ratiø between the age of the last main orogenic deformation affecting the rock mass (in years $\times 10^{-3}$ ) and maximum overburden thickness (in metres). Main -rogenic deformations are considered as Hercinian and Alpine in Spain and Italy. The age of these folds is of the order of $\mathbf{3 0 0}$ million years for the Hercinian and 10-12 million for the Alpine. Maximum overburden thickness refers to the existing overburden plus that supported by the rock mass thrøughøut its ge $\bullet$ gical history, which could be absent because of erøsion processes.

(d) seismic activity in the zone.
No specific analyses are require to calculate these parameters, but rather an approximation based on gelogical data, in søme cases taken from the literature. An example of how state of stress parameters are estimate is presented below.

Turmel excavated in Palaeozøic shales and sandstones for which the following data were obtained:

- mean density: $2.1 \mathrm{t} / \mathrm{m}^{3}$

- mean uniaxial compressive strength: $1,500 \mathrm{t} / \mathrm{m}^{2}$ (15 $\mathrm{MPa})$

- present $\bullet$ verburden thickness: $300 \mathrm{~m}$

- age of folding: Hercinian, approximately 300 million years

- maximum •verburden thickness: $500 \mathrm{~m}$ (actual -verburden thickness $300 \mathrm{~m}$ plus $200 \mathrm{~m}$ •f eroded materials according to regional ge logical data).

- competence factor: $1500 / 300 \times 2.1=2.3(-10$ pøints).

(a) tectonic accidents: faults of regiønal significance in the turmel area ( -5 points).

(b) stress relief factor: $\left\{300,000,000\right.$ years $\times 10^{-3}$ / $500 \mathrm{~m}\}=600$ (0 p॰ints) 


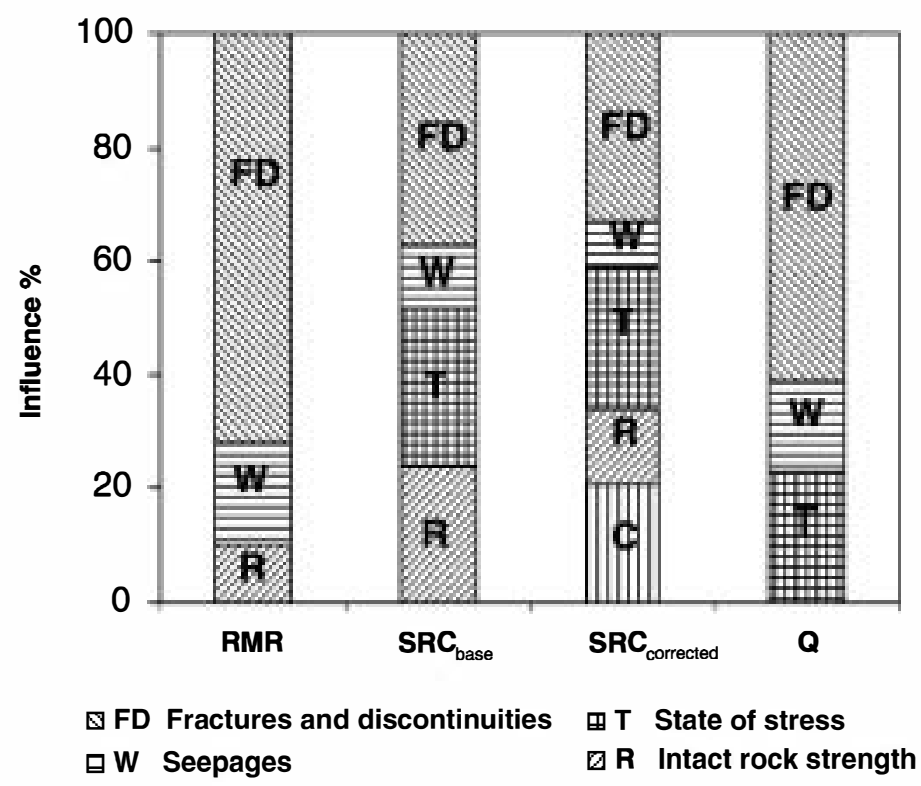

ए C Construction conditions

Fig. 1. Relative influence of the geomechanical parameters in RMR, Q and SRC rockmass classification.

(c) seismic activity: none ( 0 points).

(d) total state of stress score: $-10-5+0+0=-15$ points.

Fig. 1 shows the relative influence of the different factors contributing to SRC, RMR and $Q$ indices. Whereas the state of stress does not contribute to the RMR index, the strength of the intact rock is not included in $Q$.

\section{Tunnels under high tectonic stress}

The expansion of rapid transport systems, mainly railways and roads, has meant that many tunnels have been constructed in Spain and Italy in the last decade. Twenty-five tunnels from these countries were analysed, since it was observed that the support measurements estimated according to RMR classification were much lower than those required to stabilise deformations occurring during construction. These tunnels have been described in detail by Encinas (1992), Alfani (1993), Alfani et al. (1994) Bellini (1998) and González de Vallejo (1998). Table 5 includes some relevant data on these tunnels. Despite showing highly variable conditions both in geological and construction terms, these tunnels share the following features:

- located in Spain and Northern Italy, mostly for high-speed railways,

- sections up to120 $\mathrm{m}^{2}$,

- predominance of low strength rocks (shales, schists, argillites, etc.),

- significant folding and deformation structures (folds, faults, thrusts, etc.),

- overburden thicknesses up to $700 \mathrm{~m}$.

In 22 of the 25 cases, the main type of rock was of low strength, with typical strength values of 10-15 MPa. These weak rocks were composed of shales, schists and argillites which show highly anisotropic behaviour.

The state of stress was evaluated by considering the following data:

- tectonic history of the region, presence of deformation structures and current tectonic regime,

- in situ stress measurements, 
Table 5

Tunnels analysed and mean RMR, SRC and $\boldsymbol{Q}$ values

\begin{tabular}{|c|c|c|c|c|c|c|c|c|c|c|c|c|c|c|}
\hline No. & Ref. ${ }^{a}$ & Location $^{b}$ & $H^{\mathrm{c}}(\mathrm{m})$ & Lithology & $\begin{array}{l}\sigma_{\mathrm{c}}^{\mathrm{d}} \\
(\mathrm{MPa})\end{array}$ & $\begin{array}{l}\text { In situ } \\
\text { stress }^{e}\end{array}$ & Type & $\mathbf{R M R}{ }^{* \mathrm{f}}$ & SRC & RMR & $\begin{array}{l}\mathbf{R M R}^{* /} \\
\text { SRC }\end{array}$ & $\begin{array}{l}\mathbf{R M R}^{* /} \\
\mathbf{R M R}\end{array}$ & 2 & $\mathbf{Q}^{* \mathbf{E}}$ \\
\hline 1 & 1 & AVE $M-S$ & $<150$ & Shales & $5-15$ & High & I & 17 & 25 & 46 & 0.68 & 0.37 & NA & NA \\
\hline 2 & 1 & AVE $M-S$ & & Shales & & High & I & 18 & 57 & 60 & $\bullet .32$ & $\bullet .30$ & & \\
\hline 3 & 1 & AVE $M-S$ & & Shales & & High & I & 19 & 27 & 52 & 0.70 & 0.37 & & \\
\hline 4 & 1 & AVE $M-S$ & & Shales & & High & I & 18 & 24 & 45 & 0.75 & 0.40 & & \\
\hline 5 & 1 & AVE $M-S$ & & Shales & & High & I & 16 & 26 & 48 & 0.62 & 0.33 & & \\
\hline 8 & 1 & AVE $M-S$ & & Shales & & High & I & 30 & 30 & 54 & 1.00 & 0.56 & & \\
\hline 9 & 1 & AVE $M-S$ & & Shales & & High & I & 34 & 34 & 64 & 1.00 & 0.53 & & \\
\hline 10 & 1 & AVE $M-S$ & & Shales & & High & I & 34 & 60 & 68 & 0.57 & 0.50 & & \\
\hline 11 & 2 & $\begin{array}{l}\text { TAV G-M } \\
\text { (Val Lemme) }\end{array}$ & $100-250$ & $\begin{array}{l}\text { Argillites } \\
\text { and Shales }\end{array}$ & $<10$ & High - very high & I & 16 & 22 & 38 & $\bullet .73$ & 0.42 & & \\
\hline 12 & 3 & $\begin{array}{l}\text { CF S-V } \\
\text { (Savona) }\end{array}$ & 250 & Gneiss & $10-20$ & High - very high & II & 26 & 31 & 56 & 0.84 & 0.46 & & \\
\hline 14 & 3 & $\begin{array}{l}\text { LF V-G } \\
\text { (Genoa) }\end{array}$ & & Meta-Basalts & $30-60$ & High - very high & II & 35 & 37 & 66 & 0.95 & $\bullet .53$ & & \\
\hline 15 & 3 & $\begin{array}{l}\text { LF V-G } \\
\text { (Genoa) }\end{array}$ & & Schists & $<15$ & High - very high & II & 35 & 35 & 47 & 1.00 & 0.74 & & \\
\hline 16 & 4 & $\begin{array}{l}\text { Peñarroya } \\
\text { (Córdoba) }\end{array}$ & $400-600$ & Shales & $10-20$ & High & II & 33 & 41 & 41 & 0.80 & 0.80 & 1.3 & 0.4 \\
\hline 17 & 4 & $\begin{array}{l}\text { Peñarroya } \\
\text { (Córdoba) }\end{array}$ & & Shales & & High & II & 28 & 33 & 47 & 0.85 & 0.60 & & \\
\hline 18 & 4 & $\begin{array}{l}\text { Andorra } \\
\text { (Teruel) }\end{array}$ & & Shales & $5-10$ & Moderate & II & 24 & 31 & 34 & 0.77 & 0.71 & - .4 & 0.2 \\
\hline 19 & 4 & $\begin{array}{l}\text { Peñarroya } \\
\text { (Córdoba) }\end{array}$ & & Shales & $10-20$ & High & II & 15 & 17 & 54 & 0.88 & 0.28 & 1.3 & 0.4 \\
\hline
\end{tabular}

NA: not available.

a (1) Encinas (1992), (2) Bellini (1998), (3) Alfani et al. (1994), (4) González de Vallejo (1998).

b AVE M-S: High-Speed Railway Madrid-Seville. TAV G-M: High-Speed Railway Genoa-Milán. LF VG: Railway Volwi-Genoa. CF SV: Railway Link Savona-Vado. SH=hydraulic scheme.

${ }^{\mathrm{C}} H$ : overburden thickness $(\mathrm{m})$.

- $\sigma_{\mathrm{c}}$ : uniaxial compressive strength.

${ }^{\circ}$ Low: $\sigma H / \sigma V \leq \boldsymbol{0}$, moderate: $\sigma H / \sigma V \leq 1 . \mathbf{0}$, high $\sigma H / \sigma V \geq 1 . \mathbf{0}$, very high $\sigma H / \sigma V \geq 2.0$.

${ }^{\mathrm{f}} \mathbf{R M R} *$ : RMR value corresponding to the support actually installed.

s*: $Q$ value corresponding to the support actually installed.

- instability problems arising during excavation and their relation to tectonic structures.

In situ stress measurements carried out in the regions where the turmels were excavated have shown high values of $K\left(K=\sigma_{\mathrm{H}} / \sigma_{\mathrm{V}}\right)$ ranging from 1.3 to 2.0 in central and southern Spain. The case histories cited in Table 5 as numbers $1-10,16,17$ and 19 refer to tunnels løcated in these areas (Gønzález de Vallej• et al., 1988). High $K$ values in the range $1.5-3.0$ have 
als been reported for northern Italy (Martinetti and Ribacci, 1980; Crivelli et al., 1994) and correspond to the areas of case histories numbers $11-15$ and 20.

Based on the above-mentioned data, the state of stress was assessed as follows:

- High tectonic stress was considered for turmels under compressive tectonic regimes, mainly situ- ated in zones of Alpine folding expected to show high horizontal stresses.

- Moderate tectonic stress was assumed for tunnels mostly located in Palae zoic massifs folded in the Hercinian that were frequently affected by later tectonics of the extension type and alsø for those located in zones undergøing erosion processes.

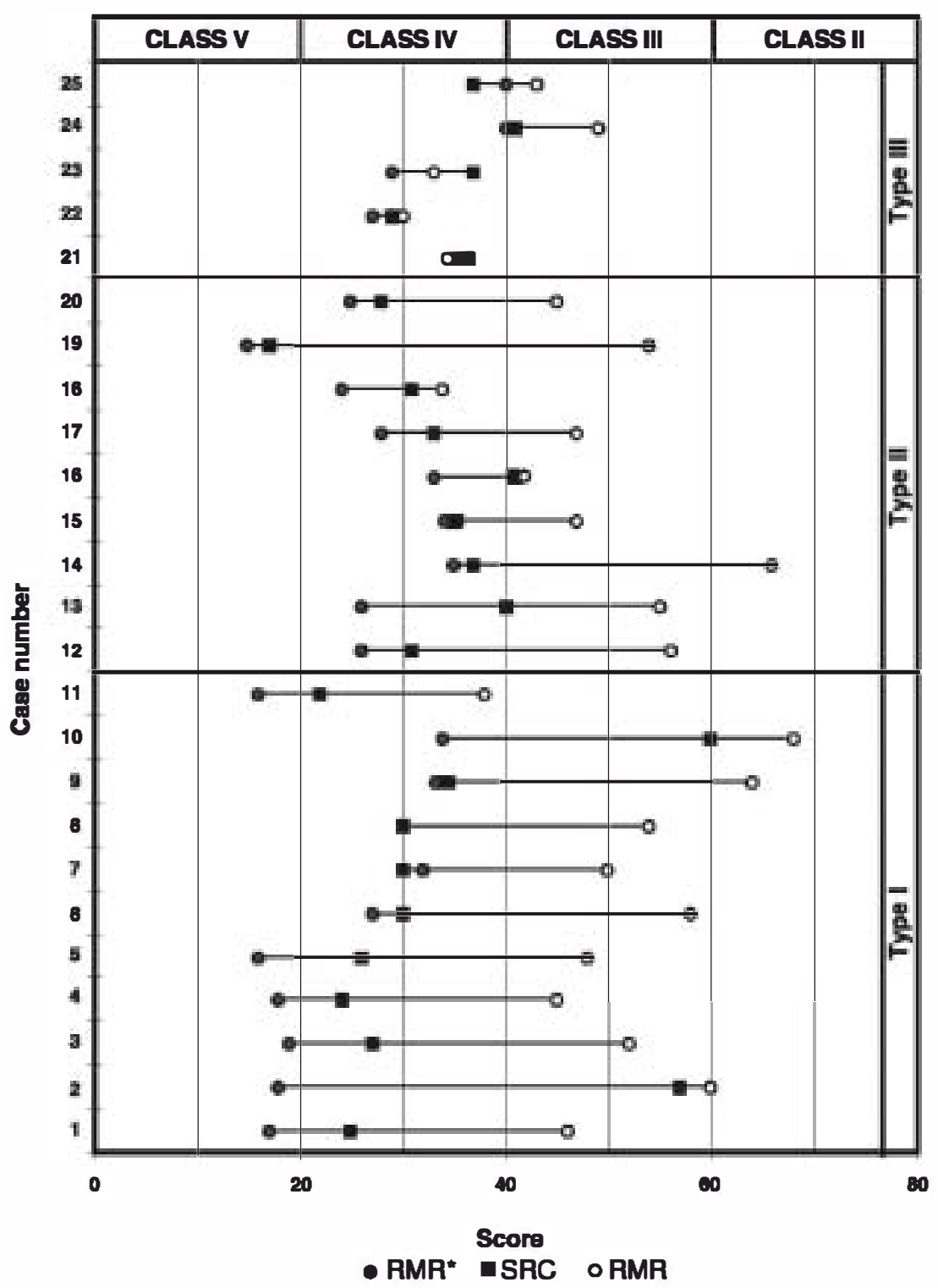

Fig. 2. Variation intervals of $\mathbf{R M R}$ and SRC indices with respect to $\mathbf{R} M \mathbf{R}^{*}$ in the study cases. 


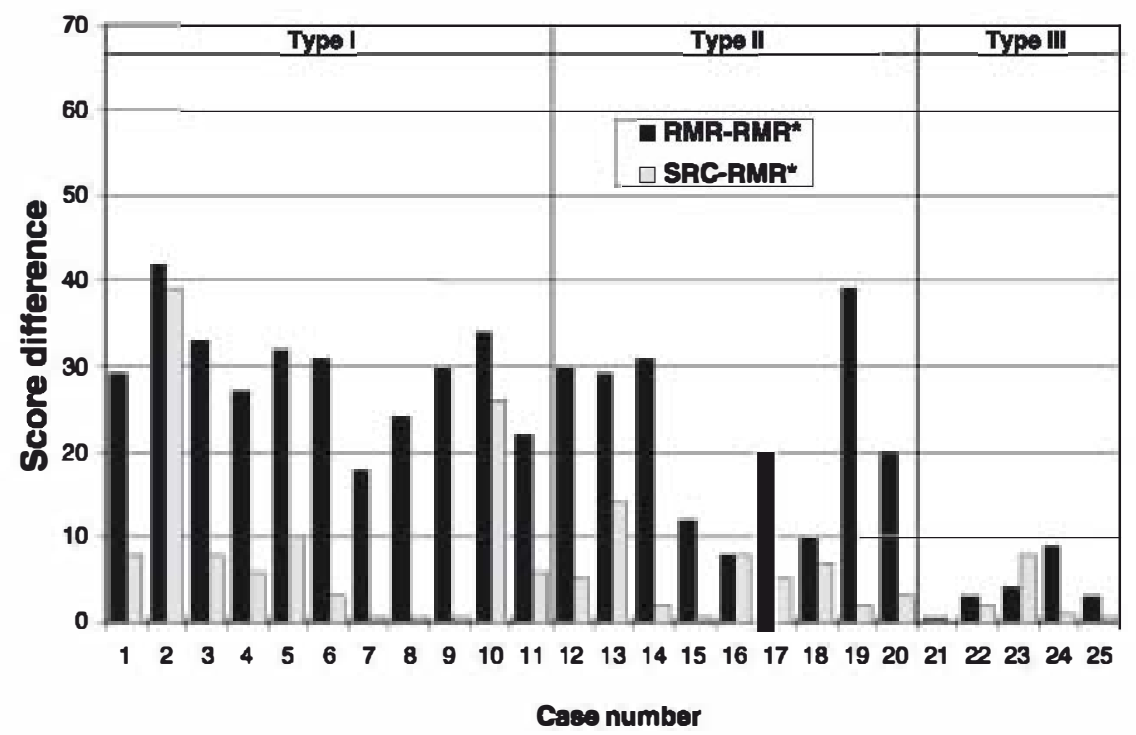

Fig. 3. Score differences between $\mathbf{R M R}$ and SRC indices with respect to $\mathbf{R} M \mathbf{R}^{*}$ for the study cases.

The following information was alsø analysed for each turmel:

- Prøject stage: geølogical and geømechanical data, RMR and SRC indices, and recommended supports according to these classifications.

- Construction stage: gelogical and geomechanical data from the excavation fronts, RMR and SRC indices, section convergence, problems related to instability and supports installed.

Measurements of the supports installed in the turmels were assigned to one of the five classes described in Table 4. Though a simplification, this classification was nevertheless useful for establishing comparative criteria for the different types of support installe in the turmels.

The RMR and SRC indices measured at the excavation fronts were compared with those estimated in the project. When the supports installed were significantly different from those predicted by the classification score, the RMR corresponding to the support installe was calculated, yielding an empirical RMR value denoted RMR*. The RMR* was determined either from direct measurements at the excavation front or by back analysing the support installed. Mean RMR* values are shown in Table 5, and the differ- ences between RMR* and RMR or SRC are represented in Figs. 2 and 3. In some cases, $\boldsymbol{Q}$ and $\mathbf{Q}^{*}$ values were alsø $\bullet$ btained (Table 5).

\section{Results}

The turmels examined were classified inte three types:

- Type I: tunnels located in zones subjected to high horizontal tectonic stresses with low overburden thicknesses (generally less than $150 \mathrm{~m}$ ).

- Type II: tunnels located in zones subjected to high hørizontal tectonic stresses with high overburden thicknesses (higher than $150 \mathrm{~m}$, but generally more than $250 \mathrm{~m}$ ).

- Type III: turmels located in zones of low to moderate tectonic stresses, irrespective of ๑verburden thickness.

T• evaluate differences between the rock mass classifications results and rock mass behaviøur after excavation, the ratios RMR*/SRC and RMR*/RMR and the differences in rock class between RMR* and RMR, and between RMR* and SRC were calculated for each type of tunnel. The results shown in Table 6 


\begin{tabular}{|c|c|c|c|c|c|c|c|c|}
\hline \multirow[t]{3}{*}{ Type } & \multirow[t]{3}{*}{$\mathbf{R M R} * / \mathrm{SRC}($ mean) } & \multirow[t]{3}{*}{$\mathbf{R M R} * / \mathbf{R M R}($ mean) } & \multicolumn{6}{|c|}{ Difference in rock class with respect to $\mathbf{R M R}^{*}(\%)$} \\
\hline & & & \multicolumn{2}{|c|}{ Same class } & \multicolumn{2}{|c|}{ One class } & \multicolumn{2}{|c|}{ Two classes } \\
\hline & & & SRC & $\mathbf{R M R}$ & SRC & $\mathbf{R M R}$ & SRC & $\mathbf{R M R}$ \\
\hline I & 0.75 & 0.44 & 36 & - & 55 & 36 & 9 & 64 \\
\hline II & 0.84 & $\bullet .56$ & 78 & 11 & 22 & 67 & $\bullet$ & 22 \\
\hline III & 0.95 & 0.91 & 100 & 100 & - & - & $\bullet$ & - \\
\hline
\end{tabular}

indicate that most differences between the RMR* and RMR or SRC were shown by type I turmels under high tectonic stress with low overburden thicknesses. Mean RMR*/SRC and RMR*/RMR ratios were 0.75 and 0.44 , respectively. Type II tunnels showed the same tendency but yielded somewhat higher values for these ratios; 0.84 for RMR*/ SRC and 0.56 for $\mathrm{RMR}^{*} / \mathrm{RMR}$. The rati with respect to RMR* was close to 1.0 in both cases for type III turmels; 0.95 for RMR*/SRC and 0.91 for RMR*/RMR.
Table 6 als shøws the differences in rock classes between RMR* and RMR, and between RMR* and SRC. RMR* was always lower or equal to the RMR or SRC indices, which meant that supports heavier than predicted were installed. $100 \%$ of cases showed differences in classes between RMR* and RMR, compared to $64 \%$ between RMR* and SRC. Greatest differences were recorded for type I turmels, which showed a difference of tw॰ classes between RMR* and RMR in $64 \%$ of the cases analysed, versus $9 \%$ between RMR* and SRC. In type II turmels, where

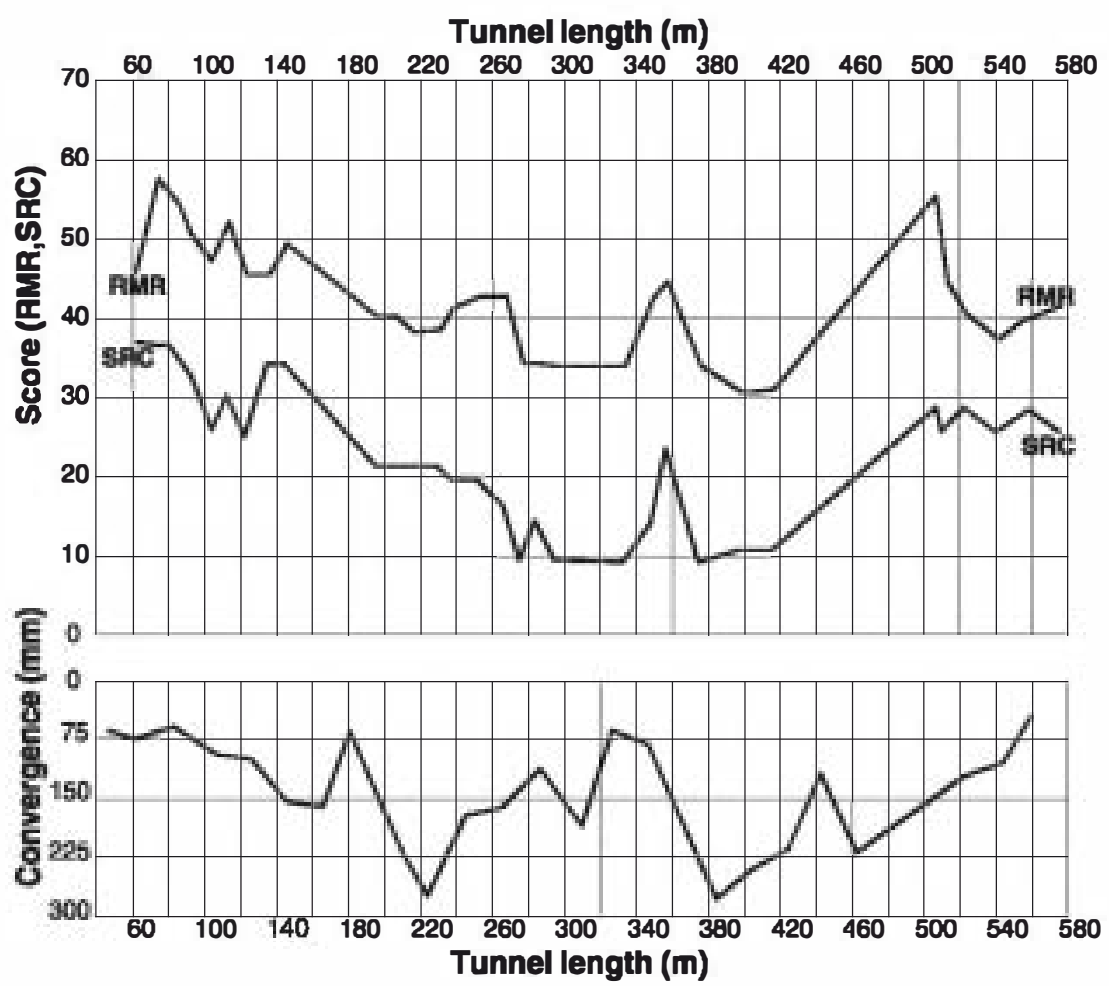

Fig. 4. RMR and SRC indices and convergence values for the Val Lemme Tunnel, a tunnel with a thin overburden and schistosity parallel to the tunnel axis (Bellini, 1998). 
$\mathbf{8 9 \%}$ of all cases showed class differences between RMR* and RMR, and $22 \%$ between RMR* and SRC, the greatest percentage corresponded to a difference of -ne class of rock in $67 \%$ of cases between RMR* and RMR; n• significant class differences between RMR* and SRC being noted in $78 \%$ of cases. For the type III tunnels, both RMR and SRC presented the same class of røck as RMR*. Før types I and II, the means of these ratios were: $\mathrm{RMR}^{*} / \mathrm{RMR} \approx \mathbf{0 . 5}$ and $\mathrm{RMR}^{*} /$ $\mathrm{SRC} \approx \mathbf{0 . 8}$.

The $\boldsymbol{Q}$ index was $\bullet$ nly determined in søme cases, thus, the same comparative criteria as for RMR and SRC could not be established. The results for type II tunnels, corresponding to cases 16,17 and 19 (Table 5), indicate a difference in one class of support from

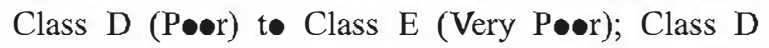
corresponds to the estimated support, and Class E to the support actually installed. For case 18, the pre- dicted type of support was the same as those actually installed. For type III tunnels, cases 21-25, installed

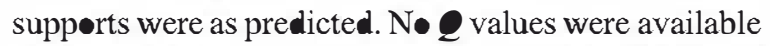
for type I tunnels. These results suggest that the $\boldsymbol{Q}$ index provides a better estimate of support requirements than the RMR for type II turmels. However, more data would be needed for comparisons with the SRC index and for type I turmels.

Highly variable relationships were observed between the deformations or convergences determined in turmel sections and RMR and SRC indices. In general, neither index could adequately predict convergence nor establish acceptable correlation between rock classification and deformation. This lack of correlation could be explained by the influence of the following key gemechanical parameters, besides construction factors not accounted for in these classification systems such as the shape and size of the
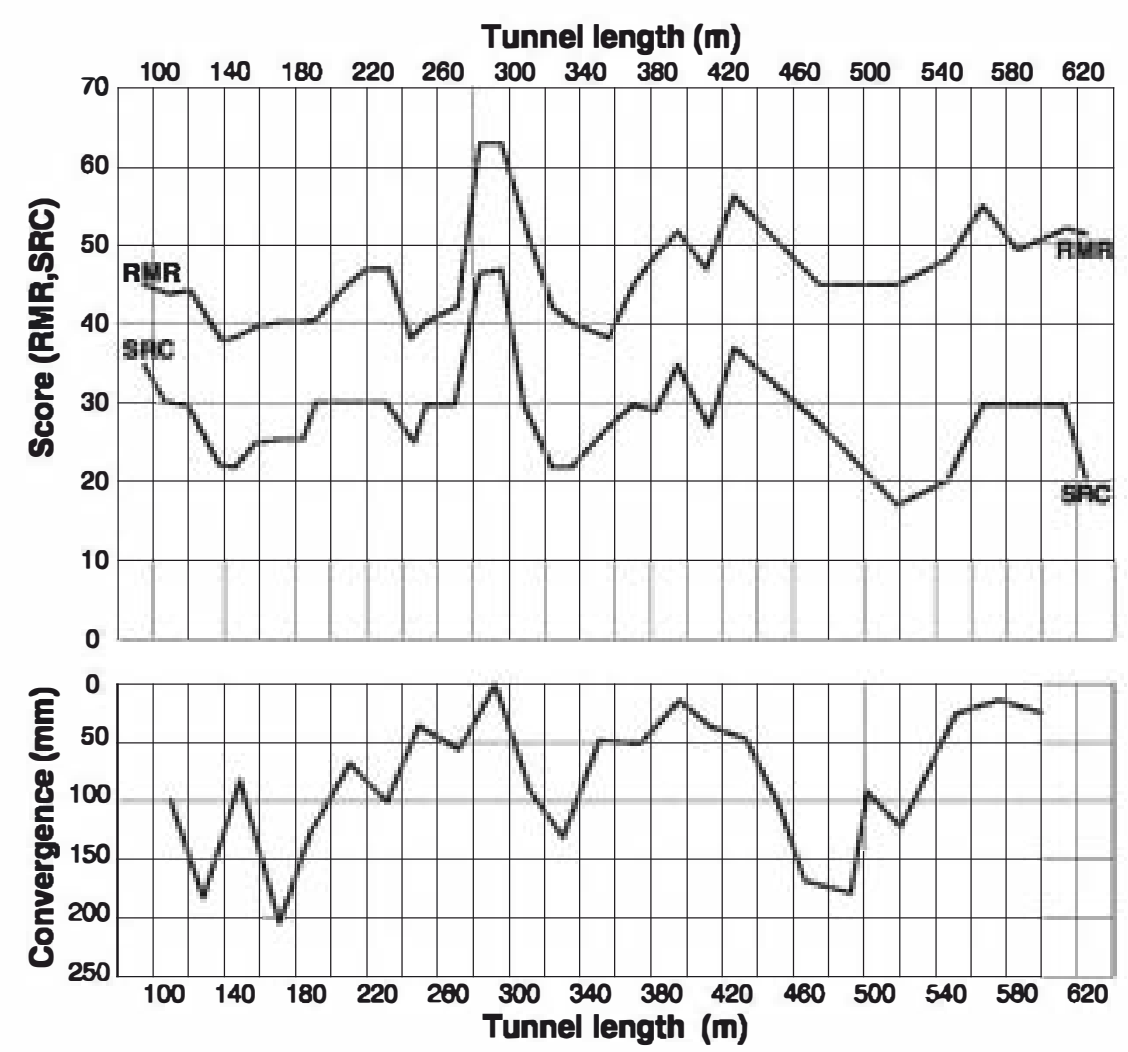

Fig. 5. RMR and SRC indices and convergence values for the Castagnola Tunnel, a tunnel with a thick overburden and schistosity perpendicular to the tunnel axis (Bellini, 1998). 
tunnel section, the excavation system and the type of support:

- high horizontal stress

- low rock strength

- thin overburden

- unfavøurable structural anisøtropy with respect t॰ tunnel axis orientation

In the tunnels examined, structural anisøtropy due to bedding planes and schistosity, and confinement degree playe a major role in deformation. In tunnels with thin overburdens, the effect of structural anistropy was marked, while this effect was much reduced in turmels with thick •verburdens. These features are shown in Figs. 4 and 5. In Fig. 4, correlation between deformations and RMR and SRC indices is low for a tunnel $\bullet$ thin $\bullet$ verburden with schist $\bullet$ sity parallel to the tunnel axis, while Fig. 5, in which correlation is much improved, corresponds to a tunnel of thick -verburden with schist osity perpendicular to the tunnel axis (Bellini, 1998).

\section{Conclusions}

The results presented in this investigation, allowed us to compare supports determined according to SRC and RMR indices with those actually installed. In the majority of the tunnels investigated, heavier supports were used than these predicted by RMR. Systematic analysis during excavation of gemechanical data, SRC and RMR indices, in situ stress and tunnel section deformability served to identify the main geomechanical factors contributing to underestimation of supports as:

- high horizontal tectonics stress

- low rock strength

- thin everburden

- highly anisøtrøpic rock behaviøur.

The results of applying SRC and RMR indices to the 25 tunnels analysed can be summarised by the following types of behaviour:

- Type I. Shallow tunnels under high horizontal tectonic stress excavated in weak rocks. In these tunnels, highly anisøtropic rockmass behaviøur depends on structural anisøtrøy and its •rientation with respect to the tunnel axis. The supports installed in all cases were much heavier than those estimated by the RMR index: 64\% of cases showed a difference of two classes and 36\% showed a difference of one class, thus, accounting for all the tunnels of this type. However, corresponding results for the SRC index were $\mathbf{9 \%}$ showing a two-class difference, $55 \%$ a difference of $\bullet$ ne class and $36 \%$ showing the same class. Correlations between SRC or RMR indices and convergence measurements in tunnel sections were low for these turmels.

- Type II. Tunnels with high overburden thickness, high horizontal tectonic stress and low strength røcks. Røck mass behaviour is less anisøtropic than for type I tunnels, and RMR or SRC indices correlated well with tunnel convergence. Supports installe in $78 \%$ of cases were the same as those estimated by the SRC index, while the RMR underestimated supports in $89 \%$ of these tunnels.

- Type III. Tunnels under low to moderate hørizontal tectonic stress regardless of overburden thickness excavated in weak rocks. The supports installed were consistent with those predicted by both the RMR and SRC indices.

In general, these findings indicate that the SRC index provides a reasønable estimate of turmel support in tumels under high horizontal tectonic stress excavated in weak rocks. In contrast, under the conditions of the present analysis, the RMR can underestimate support requirements by one or twe classes $\bullet$ r rock.

\section{Acknowledgements}

The auther thanks Dr. Marin॰ Trimbøli and Dr. Sergiv Pedemente for their valuable contributions to this study. The authors of theses on rock mass classification undertaken at the Universidad Complutense de Madrid (Valeria Bellini, Ignaci Encinas and Luis Muñøz) and at the Universita di Genøva (Marc॰ Alfani) are alsø gratefully acknøwledged. Thanks are alsø due to Dr. M. Ferrer and Sr. J.M. Insua for their help during preparation of the paper. 


\section{References}

Alfani, M., 1993. Le classificazioni geomeccaniche di Gonzalez de Vallejo (1983) e Romana (1990) applicate al alcuni litotigi lig. uri: correlazioni con la progettazioni di opere in sotterrares. Tesis, Universita di Genova.

Alfani, M., Nosengo, S., Pedemonte, S., 1994. La classificazioni geomeccaniche SRC di González de Vallejo (1983) e SMR di Romana (1990): considerazioni e proposta. Professione Geologo 3, 12-20 (Genova).

Barton, N., Grismtad, E., 1994. The Q-System following twenty years of application in NATM support selection. Geomechanics Felsbau 12, 6.

Barton, N., Lien, R., Lunde, J., 1974. Engineering classification of rock masses for the design of tunnel support. Rock Mechanics 6 (4), 189-236.

Bellini, V., 1998. Caracterización geomecánica de rocas blandas: metodologías de clasificación y medidas de convergencia en las galerias de exploración para el proyecto del tren de alta velocidad Génova-Milán. Tesis del Master de Ing. Geológica, Universidad Complutense de Madrid.

Bieniawski, Z.T., 1973. Engineering classification of jointed rock masses. The Civil Engineer in South Africa 15 (12), 335-344.

Bieniawski, Z.T., 1979. The geomechanics classification in rock engineering applications. 4th Int. Congress Rock Mechanics, Montreaux, vol. 2. Balkema, Rotterdam, pp. 41-48.

Bieniawski, Z.T., 1989. Engineering Rock Mass Classifications. Wiley, Chichester.

Crivelli, R., Devin, P., Guido, S., Rossi, P.P., 1994. Indagini in sito e in laboratorio per il Progetto e l'essecuzione di Gallerie Pro- fonde. In: Barla, G. (Ed.), Conf. on Mechanics and Engineering of Rocks, MLR'94, Torino, vol. 2, pp. 1-17.

Encinas, I., 1992. Aplicaciones de las clasificaciones geomecánicas en rocas blandas a partir de datos del frente de excavación. Tesis del Master de Ing. Geológica, Universidad Complutense de Madrid.

González de Vallejo, L.I., 1983. A new classification system for underground assessment using surface data. IAEG Symp. on Eng. Geol. and Underground Constuction, Lisboa 2. Balkema, Rotterdam, pp. 85-94.

González de Vallejo, L.I., 1985. Tunnelling evaluation using the Surface Rock Mass Classification System SRC. ISMR Symp. The Role of Rock Mechanics in Excavations for Mining and Civil Works, Zacatecas, México, vol. 1. Soc. Mexicana de Mec. de Rocas, Mexico, D.F., pp. 458-466.

González de Vallejo, L.I., 1998. Las clasificaciones geomecánicas para tíneles. In: López, J. (Ed.), Ingeotúneles, vol. 1. Entomo Gráfico, Madrid, pp. 25-68. Cap 1.

González de Vallejo, L.I., Serrano, A.A., Capote, R., De Vicente, G., 1988. The state of stress in Spain and its assesment by empirical methods. Rock Mech. and Power Plants. ISRM Symp., vol. 1. Balkema, Rotterdam, pp. 165-172.

Herget, G., 1988. Stresses in Rock. Balkema, Rotterdam.

Hoek, E, Brown, E.T., 1980. Underground Excavation in Rock. Inst. Min. and Met., London.

Hudson, J.A., Harrison, J.P., 1997. Engineering Rock Mechanics. An Introduction to the Principles. Pergamon, Oxford.

Martinetti, S., Ribacci, R., 1980. In situ stress measurements in Italy. Rock Mechanics (Suppl. 9), 31-47. 